\title{
CASH BUDGET DALAM SISTEM BISNIS SYARIAH
}

\author{
Muhammad Muflih ${ }^{1}$
}

\begin{abstract}
Studi ini membuktikan bahwa cash budget yang dilaksanakan dalam sistem bisnis syariah dapat memberikan solusi yang efektif dalam perencanaan bisnis bagi hasil dan sekaligus dapat memberikan solusi yang sangat baik dalam permasalahan biaya dan defisit. Pilar terbangunnya cash budget yang Islami adalah sistem permodalan bagi hasil mudharabah di mana pemodal (shabib al-mal) memberikan sokongan keuangan yang sangat kuat dan siap bekerjasama dalam menghadapi risiko biaya dan defisit, pola penerimaan yang sesuai dengan prinsip syariah, pola pengeluaran yang sesuai dengan prinsip syariah, dan langkah penyelesaian defisit yang adil dan tepat. Dalam hal penyelesaian defisit, besarnya penambahan biaya ditentukan oleh nilai saldo yang wajar dan defisit riilnya.
\end{abstract}

Keywords: Cash Budget, Mudharabah, Sistem Bisnis Syariah

\section{Pendahuluan}

Sebuah perusahaan yang dibangun berdasarkan sistem ekonomi syariah pada umumnya menggunakan mudharabah sebagai basis sistem keuangan di mana sistem tersebut membiayai semua aktifitas produktif yang dijalankan oleh perusahaan. Sistem ini menghubungkan pihak shahib al-mal yang membiayai seluruh kegiatan perusahaan dan disebut sebagai pemilik perusahaan dengan pihak mudharib yang menjalankan aktifitas bisnis perusahaan sampai ketika usaha tersebut memperoleh suatu tingkat keuntungan keduanya melakukan bagi hasil.

Para ahli di bidang ekonomi syariah memandang bahwa posisi mudharabah sangat strategis dalam setiap aktifitas keuangan perusahaan Islami. Mudharabah dipandang memiliki kemampuan yang sangat lengkap dalam kegiatan-kegiatan bisnis syariah. Itulah sebabnya para pakar menempatkan akad ini sebagai pengganti yang pantas atas akad investasi berbasis bunga bank. Namun demikian, para pakar belum memberikan penjelasan yang sempurna

\footnotetext{
${ }^{1}$ Dosen Teknik Politeknik Negeri Bandung, Indonesia (muflih64@hotmail.com)
} 


\section{Cash Budget dalam Sistem Bisnis Syariah}

mengenai bagaimana ketika suatu bentuk investasi mudharabah menghadapi masalah biaya dan defisit. Permasalahan biaya dan defisit ini merupakan bagian dari risiko yang perlu mendapat jawaban yang tepat.

Sesungguhnya para pakar telah berupaya memberikan penjelasan yang menarik tentang hubungan antara bisnis mudharabah dengan pengendalian risiko. Namun demikian, penjelasan tersebut masih terlalu teoretik dan belum masuk ke dalam dimensi yang sangat aplikatif. Misalnya, Masudul Alam Choudhury dalam Contribution to Islamic Economic Theory A Study in Social Economics (1986, 81-84) menjelaskan bahwa pengusaha mudharib yang mampu melakukan diversifikasi risiko yang sangat baik yang berakibat pada mampunya perusahaan meningkatkan perolehan laba akan mendapatkan kepercayaan yang lebih tinggi dari pihak investor. Investor tersebut akan memperpanjang jangka waktu investasi menjadi lebih lama. Secara matematis hal ini dijelaskan, jika dalam sebuah model $d p_{k} / d p_{j}=\left(1+C_{A} / C p\right)$ ditemukan bahwa $d p_{k}>d p_{j}$, di mana dalam temuan tersebut nasabah mudharib berhasil menunjukan diversifikasi risiko yang mampu meningkatkan keuntungan bagi pihak investor mudharabah, maka pihak investor mudharabah akan memperpanjang investasi tersebut pada waktu $d p_{k}$. Melalui teoretisasi ini Choudhury berpendapat bahwa kepercayaan investor dalam investasi mudharabah terukur menurut diversifikasi risiko yang dilakukan oleh pihak pengusaha mudharib. Senada dengan Choudhury, M. Fahim Khan dalam Essays in Islamic Economics (1995, 176) menjelaskan bahwa kemampuan investasi mudharabah mencapai tingkat keuntungan yang tinggi juga sangat ditentukan oleh kemampuan pihak mudharib mendiversifikasi portofolio, yang dalam hal ini dimaksudkan adalah diversifikasi risiko.

Kedua pendapat di atas menempatkan faktor diversifikasi risiko yang dilakukan oleh pihak pengusaha mudharib sebagai kunci tercapainya target keuntungan perusahaan bahkan hingga mencapai tingkat keuntungan yang sangat tinggi. Namun demikian, dalam tulisan kedua pakar tersebut tidak ditemukan rumusan instrumen bisnis yang dapat mencapai sasaran bisnis mudharabah tersebut. Studi ini berpendapat bahwa kemampuan bisnis mudharabah mencapai tingkat keuntungan yang sangat tinggi tidak semata tergantung pada faktor diversifikasi risiko. Diversifikasi risiko merupakan sebuah strategi, ia tidak dapat dikatakan faktor yang paling menentukan dalam 
pencapaian sasaran keuntungan yang diharapkan karena operasionalnya dalam mencapai keuntungan tersebut belum diukur secara langsung. Hal ini sering menyulitkan pihak pengusaha dalam menentukan cara seperti apa yang dapat dilakukan untuk mencapai tingkat keuntungan yang diharapkan jika pilihan investasi bisnis berhasil dilakukan. Pengusaha tersebut akan sulit mencari jalan keluar jika dalam praktiknya didapatkan kendala biaya dan defisit karena faktor strategi lebih diutamakan daripada faktor instrumen operasionalnya sendiri. Ketiadaan instrumen pengendali risiko itulah yang menjadikan strategi bisnis mudharabah mudah menghadapi masalah. Dalam hal inilah maka faktor teknis tidak dapat diabaikan. Dengan kata lain, persoalan biaya dan defisit yang dapat dijawab secara teknis akan membantu pengusaha mudharib dalam mencapai sasaran keuntungan yang diharapkan.

\section{Permasalahan}

Berdasarkan latar belakang di atas maka yang menajdi permasalahan adalah bagaimana factor teknis dari persoalan biaya dan deficit perusahaan dapat diselesaikan oleh pengusaha. Dapat dikatakan bahwa sebuah instrumen yang dapat memprediksi solusi keuangan bisnis syariah yang menghadapi suatu tingkat risiko biaya dan defisit sangat diperlukan.

\section{Pembahasan}

Cash budget yang merupakan sebuah alat perencanaan yang dapat menunjukkan pola penerimaan dan pengeluaran kas yang dinyatakan secara kuantitatif untuk suatu periode akan datang sangat tepat untuk dijadikan sebagai instrumen prediksi keuangan bisnis syariah tersebut. Oleh karena cash budget yang terdapat sampai saat ini masih beroperasi secara konvensional di mana bunga menjadi instrumen solusi yang sangat utama, maka tantangan yang dihadapi ialah bagaimana membentuk hal tersebut tanpa bunga. Alasan peniadaan bunga dalam cash budget untuk bisnis syariah ialah karena bunga sama dengan riba, dan riba sangat diharamkan dalam hukum Islam. Sebagai jalan keluar atas pengharaman bunga, maka sistem bisnis Islam menawarkan konsep bagi hasil. Konsep inilah yang akan digunakan dalam membentuk cash 


\section{Cash Budget dalam Sistem Bisnis Syariah}

budget yang Islami. Studi ini akan merumuskan bagaimana bentuk operasional cash budget yang Islami yang dapat mengatasi permasalahan biaya dan defisit dalam perencanaan bisnis yang menggunakan sistem bagi hasil. Ada dua hal yang akan dirumuskan kembali dalam cash budget yang sesuai dengan sistem bisnis Islam, yaitu (1) bagaimana bentuk permodalan yang dijalankan dalam cash budget yang Islami, (2) bagaimana bentuk penyusunan pola penerimaan yang berasal dari penjualan yang Islami, baik penjualan secara tunai maupun tidak tunai dan alat apa yang diperlukan jika penjualan yang dilakukan secara tidak tunai, (3) bagaimana penyusunan pola pengeluaran yang sesuai dengan periode operasi untuk masing-masing operasi bisnis syariah, (4) langkah apa yang akan dilakukan jika terjadi defisit dalam periode yang akan datang. Jawaban atas pertanyaan-pertanyaan tersebut akan dijawab dalam studi ini.

\section{Aliran Kas dalam Sitem Bisnis Syariah}

Studi ini merumuskan aliran kas yang dapat dioperasikan dalam cash budget yang Islami sebagaimana yang dapat dilihat dalam gambar 1. Ada dua aliran besar yang terdapat di dalam aliran kas bisnis syariah, yaitu aliran finansial dan aliran operasional. Aliran finansial terbangun dari empat alur, yakni (1) alur permodalan, (2) alur bagi hasil, (3) alur pembayaran pajak dan zakat, dan (4) alur tanggungjawab sosial perusahaan.

Sistem permodalan yang digunakan adalah kerjasama mudharabah di mana modal sepenuhnya berasal dari pihak shabib al-mal, yang dalam hal ini dapat diperankan oleh individu atau perbankan syariah. Oleh karena sistem permodalan dijalankan dalam bentuk kerjasama, maka tidak terdapat sistem pembayaran biaya modal seperti yang terjadi di dalam sistem cash budget konvensional. Di dalam sistem konvensional, pihak kreditur yang dalam hal ini diperankan oleh pengusaha memiliki kewajiban dalam membayar cost of capital yang tidak lain merupakan bunga yang dibayar rutin setiap periode pembayaran. Adapun dalam sistem mudharabah cost of capital tidak diterapkan, karena di dalam sistem mudharabah shabib al-mal dan mudharib sama-sama memiliki tanggungjawab dalam suatu kerjasama yang disepakati. Jika terdapat perolehan keuntungan maka keduanya berbagi hasil dan jika terdapat kerugian keduanya menanggung kerugian masing-masing, di mana shabib al-mal 
menanggung kerugian modal dan mudharib menanggung kerugian tenaga, waktu, dan lain-lain.

Alasan lain tidak terdapatnya cost of capital ialah karena substansi mudharabah adalah ta'awun di mana kedua belah pihak yang bertransaksi tersebut sama-sama berkontribusi dalam terbangunnya proyek bisnis yang apabila salah satu pihak menghilangkan kontribusinya maka bisnis tersebut tidak dapat berjalan sama sekali. Itulah sebabnya keduanya saling membutuhkan dan saling mendukung satu sama lain.

Sedangkan alur bagi hasil merupakan alur pembagian keuntungan atas usaha yang dibiayai melalui modal mudharabah. Syarat pembagian hasil mudharabah adalah jika revenue dikurangi cost menghasilkan nilai yang positif. Jika mudharabah menghasilkan nilai yang negatif maka yang dilakukan adalah loss sharing, bukan profit sharing. Oleh karena kedua belah pihak menerima profit sharing, maka perlu dijelaskan bagaimana pola pembayaran bagi hasil tersebut. Dalam hal ini, modal berasal dari pihak shabib al-mal. Alur permodalan dicatat dari sisi kepemilikan shabib al-mal. Dalam hal inilah tanggungjawab permodalan sepenuhnya berada di pihak shahib al-mal. Jika terjadi defisit modal maka pihak shahib al-mal mengambil peran dalam mengatasi defisit tersebut. Ketika terjadi perolehan keuntungan, maka pencatatan yang dilakukan adalah memindahkan dana total biaya ke dalam modal dan mengungkap berada nilai keuntungan yang diperolah dari bisnis mudharabah. Lalu mengkalikan persentase bagi hasil keuntungan bisnis tersebut. Dalam hal ini dapat dimisalkan shabib al-mal menerima 60\% dan mudharib menerima 40\%. Ketika bagi hasil bagi setiap pihak telah terhitung dengan jelas, langkah selanjutnya adalah mengeluarkan nilai bagi hasil tersebut kepada kedua belah pihak. 


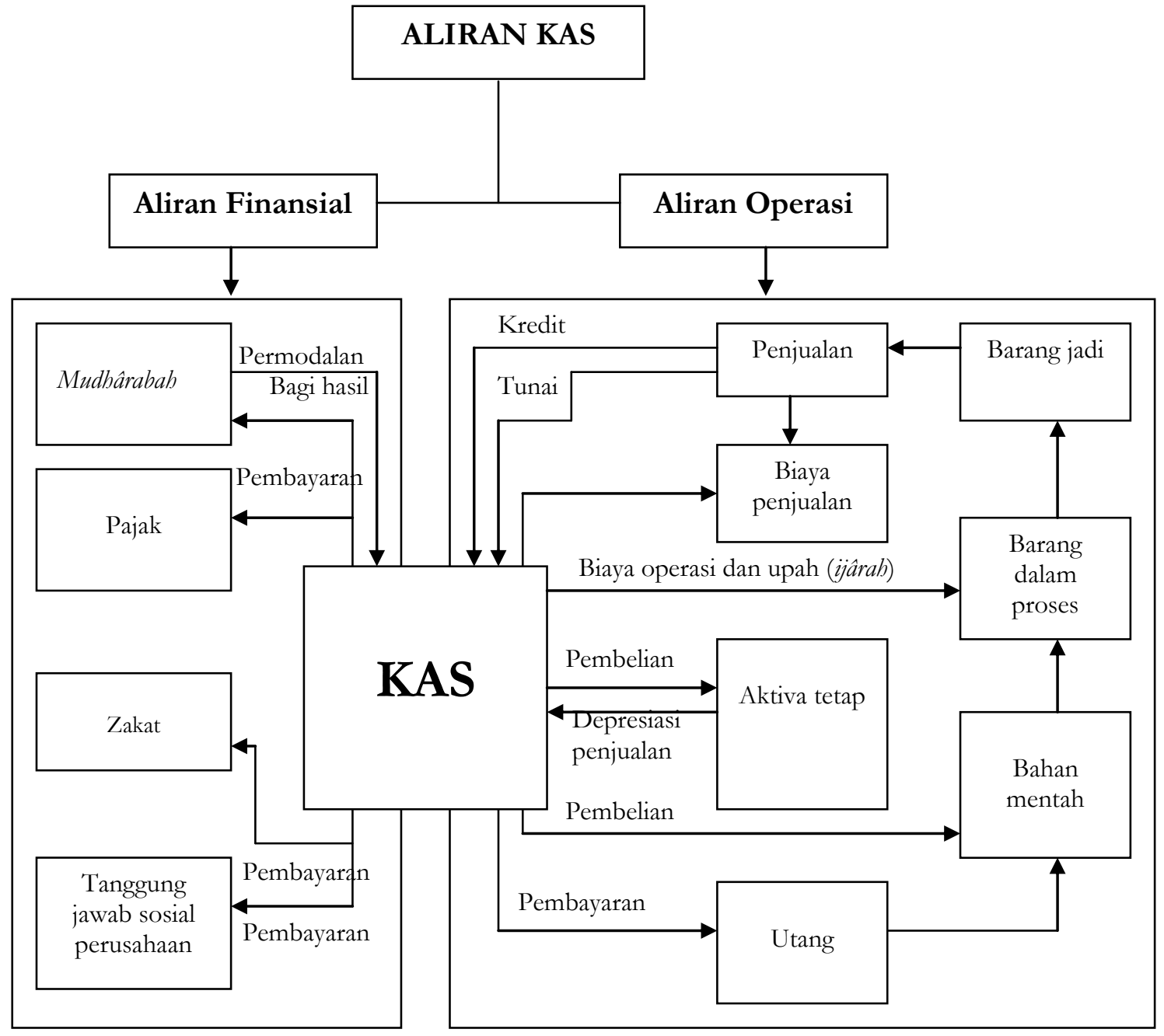

Gambar 1. Aliran Kas dalam Perusahaan Islami

Sedangkan alur pembayaran pajak dan zakat merupakan pembayaran yang wajib dikeluarkan atas perolehan bisnis mudharabah. Kewajiban zakat juga dilaksanakan atas kondisi nilai aset yang dimiliki oleh perusahaan. Dalam bisnis ini, zakat yang dilakukan ada dua yaitu zakat harta perniagaan dan zakat perolehan keuntungan. Dalam hukum Islam, zakat harta perniagaan adalah 2,5\% dari total harta perniagaan dan dibayarkan di akhir tahun perniagaan dengan syarat jika telah sampai satu nisab zakat emas. Sedangkan zakat perolehan bisnis dibayarkan setelah bagi hasil dikeluarkan kepada masingmasing pihak di dalam perusahaan. Baik shabib al-mal maupun mudharib 
keduanya sama-sama mengeluarkan zakat perolehan bisnis sebesar 2,5\% dan dibayarkan di akhir tahun perniagaan dan telah mencapai satu nisab zakat emas. Walaupun dalam prakteknya zakat perolehan bisnis tidak masuk ke dalam alur pengeluaran kas untuk pembayaran zakat secara langsung, namun alur tersebut dapat digunakan pada jenis zakat harta perniagaan. Bahkan di dalam hukum Islam terdapat pula zakat piutang jika perusahaan tersebut memiliki piutang dan memenuhi persyaratan penunaiannya. Sedangkan cara pembayaran pajak dirujuk kepada hukum positif yang berlaku di tempat masing-masing.

Dalam aliran kas perusahaan yang berbasis pada prinsip syariah, maka perusahaan tersebut mengorientasikan bisnisnya untuk memperbesar nilai sosial yang dalam hal ini diaplikasikan dalam alur tanggungjawab sosial perusahaan. Hal ini sepaham dengan Metwally dalam buku yang berjudul Theory and Model of Islamic Economics. Dana yang digunakan dikategorikan dalam bentuk infaq dan shadaqah. Nilai yang dikeluarkan dalam infaq dan shadaqah tersebut bisa lebih besar dari nilai zakat namun tidak memiliki batasan minimal dan maksimal. Jumlah dana yang dikeluarkan tersebut dapat ditentukan sendiri oleh pihak perusahaan, dan tidak dikaitkan langsung dengan upaya peningkatan nilai penjualan. Hal tersebut dikeluarkan semata untuk kepentingan sosial masyarakat demi mendapatkan ridha Allah.

Aliran yang tidak kalah penting dalam Islamic cash flow tersebut adalah aliran operasional. Ada lima alur utama yang terdapat dalam bagian aliran tersebut, yaitu (1) alur biaya operasi dan upah (ijarah), (2) alur penjualan kredit, (3) alur penjualan tunai, (4) alur biaya penjualan, dan (5) alur utang. Dalam alur biaya operasi, nilai biaya sangat tergantung pada jumlah fix cost dan variable cost. Biaya operasional tersebut akan menentukan berapa jumlah bahan mentah yang dibutuhkan sampai berapa nilai upah (jjarab) yang dibayarkan kepada pegawai. Biaya yang dikeluarkan tersebut selanjutnya menggerakkan kegiatan operasional yang pada akhirnya menghasilkan barang jadi. Barang jadi tersebut dijual kepada publik baik melalui sistem penjualan kredit maupun sistem penjualan tunai. Jika yang dilakukan adalah sistem penjualan kredit, maka akad yang digunakan adalah murabahah. Perusahaan perlu menyediakan alat pencatatan khusus di bidang penjualan murabahah yang dapat mewadahi pencatatan periodikal. 


\section{Cash Budget dalam Sistem Bisnis Syariah}

Dalam hal ini tidak menutup kemungkinan jika perusahaan berutang kepada pihak lain yang disebabkan oleh hambatan pembayaran atau hambatan lainnya. Utang tersebut bisa diaplikasikan dalam akad qardh, bisa pula dalam akad kafalah bi al-ujrah, atau jenis akad lain. Perusahaan akan melakukan pembayaran apabila telah jatuh tempo. Utang tersebut dilakukan sebatas melancarkan operasional bisnis perusahaan, khususnya yang berkaitan dengan pengadaaan bahan mentah atau bahan-bahan lain.

\section{Model Cash Budget Syariah}

Cash budget merupakan suatu perencanaan yang menunjukkan pola penerimaan dan pengeluaran kas yang dinyatakan secara kuantitatif untuk suatu periode yang akan datang. Dengan demikian maka cash budget dapat berfungsi sebagai alat untuk meramalkan posisi kas perusahaan pada setiap periode investasi. Dalam manajemen, cash budget dapat memberikan informasi mengenai pola penerimaan dan pengeluaran kas setiap periode operasi, sehingga perubahan-perubahan yang terjadi pada kas tersebut dapat diatasi dengan baik.

Sistem cash budget yang secara umum digunakan oleh perusahaan konvensional tidak dapat diterapkan sepenuhnya pada perusahaan Islami. Alasan yang paling terkemuka ialah bahwa perusahaan Islami mengeliminasi sistem bunga dan menggunakan sistem bagi hasil mudharabah. Dengan demikian maka sistem operasional cash budget tersebut akan mengadaptasi model-model perubahan yang terjadi dalam sistem mudharabah. Di samping itu, menu zakat juga menjadi poin pengeluaran pokok yang wajib dipenuhi oleh perusahaan jika telah memenuhi syarat minimalnya.

Langkah-langkah penyusunan cash budget yang dijalankan di bawah sistem bisnis syariah diurutkan sebagai berikut.

1. Menyusun pola penerimaan yang berasal dari penjualan, baik penjualan secara tunai maupun kredit, sesuai dengan waktu penjualan yang telah direncanakan. Apabila terjadi penjualan dengan sistem kredit, maka Receivable Collection Budget atau Budget pengumpulan piutang akan digunakan untuk membantu analisa keuangan ini. 
Jumlah piutang yang terkumpul dimasukkan ke dalam kolom penerimaan di dalam cash budget. Sistem kredit ini dapat dijalankan berdasarkan sistem murabahah, di mana perusahaan akan me-mark up nilai harga penjualan dari harga penjualan tunai. Selain itu, penerimaan-penerimaan lain yang bersifat ribawi tidak diperhitungkan, sehingga penerimaan ini hanya berasal dari hasil penjualan atau sewa komoditas yang sah menurut syariah.

2. Menyusun pola pengeluaran sesuai dengan periode operasi untuk masingmasing sektor pengeluaran, seperti.

a. Pembelian-pembelian tunai, misalnya pembelian bahan dan alat-alat, atau aktiva.

b. Pembayaran kewajiban-kewajiban.

c. Pembayaran gaji dan upah.

d. Asuransi, pajak, zakat, serta biaya-biaya operasi.

e. Pembayaran bagi hasil mudharabah.

f. Pengeluaran-pengeluaran lainnya.

Berdasarkan semua susunan tersebut maka dilakukanlah penyusunan cash budget untuk sebuah perusahaan Islami. Langkah pertama yang dilakukan adalah penyusunan Receivable Collection Budget. Hal ini dipaparkan dalam sajian tabel berikut.

\section{Tabel 1.}

Ilustrasi Receivable Collection Budget Bulanan

\begin{tabular}{|l|l|l|l|l|l|}
\hline \multicolumn{1}{|c|}{$\begin{array}{c}\text { Waktu } \\
\text { Pengeluaran }\end{array}$} & $\begin{array}{c}\text { Taksiran } \\
\text { Kredit }\end{array}$ & $\begin{array}{c}\text { Penerimaan } \\
\text { Bulan 1 }\end{array}$ & $\begin{array}{c}\text { Penerimaan } \\
\text { Bulan 2 }\end{array}$ & $\begin{array}{c}\text { Penerimaan } \\
\text { Bulan 3 }\end{array}$ & $\begin{array}{c}\text { Penerimaan } \\
\text { Bulan 4 }\end{array}$ \\
\hline $\begin{array}{l}\text { Bulan 1 } \\
\text { Bulan 2 } \\
\text { Bulan 3 }\end{array}$ & $\begin{array}{l}\text { Rp. xx } \\
\text { Rp. xx } \\
\text { Rp. xx }\end{array}$ & Rp. xx & Rp. Xx & Rp. xx & \\
\hline $\begin{array}{l}\text { Jumlah } \\
\text { piutang yang } \\
\text { terkumpul/ } \\
\text { bulan }\end{array}$ & & Rp. xx & Rp. Xx & Rp. xx & Rp. Xx \\
\hline
\end{tabular}

Dalam tabel di atas dapat dilihat bahwa penjualan dalam bentuk kredit menskemakan periodesasi pembayaran selama beberapa bulan, yang dalam contoh ini adalah empat bulan. Nilai pembayaran di setiap bulan boleh 


\section{Cash Budget dalam Sistem Bisnis Syariah}

jadi sama, boleh jadi berbeda. Semua itu dirumuskan melalui kesepakatan perusahaan dan pembeli. Jumlah piutang kredit yang berhasil dikumpulkan akan menjadi nilai pemasukan yang dapat mempengaruhi nilai cash budget berikutnya.

Setelah penyusunan Receivable Collection Budget, langkah yang selanjutnya dilakukan adalah penyusunan kolom cash budget. Hal ini diilustrasikan pada tabel 2. Dimana tabel 2 menguraikan semua bentuk transaksi usaha, mulai dari penerimaan hingga pengeluaran. Dalam alur penerimaan dan pengeluaran ini defisit sangat mungkin terjadi, di mana nilai penerimaan lebih kecil daripada nilai pengeluaran. Defisit tersebut mengakibatkan bertambahnya beban perusahaan. Solusi yang dapat dilakukan untuk mengatasi masalah ini ialah dengan cara restrukturisasi terhadap nilai modal perusahaan oleh shahib al-mal (pemodal).

Dalam restrukturisasi nilai modal perusahaan, pihak mudharib (pekerja) dan shabib al-mäl (pemodal) merumuskan kembali nilai modal yang diperuntukan untuk perusahaan. Langkah yang dilakukan ialah penambahan jumlah modal usaha agar sesuai dengan porsi yang dibutuhkan menurut kondisi perusahaan saat itu. Hal ini tentu tetap memperhitungkan aspek kehatihatian dalam menjalankan usaha.

Tabel 2.

Ilustrasi Cash Budget Bulanan

\begin{tabular}{|l|c|c|c|c|}
\hline \multicolumn{1}{|c|}{ Keterangan } & Bulan & Bulan & Bulan & Bulan \\
& 1 & 2 & 3 & 4 \\
\hline $\begin{array}{l}\text { Transaksi usaha: } \\
\text { Penerimaan: }\end{array}$ & & & & \\
Penjualan kredit & $\mathrm{xx}$ & $\mathrm{xx}$ & $\mathrm{xx}$ & $\mathrm{xx}$ \\
Penjualan tunai & $\mathrm{xx}$ & $\mathrm{xx}$ & $\mathrm{xx}$ & $\mathrm{xx}$ \\
Penerimaan lain-lain & $\mathrm{xx}$ & $\mathrm{xx}$ & $\mathrm{xx}$ & $\mathrm{xx}$ \\
Total penerimaan & $\mathrm{xx}$ & $\mathrm{xx}$ & $\mathrm{xx}$ & $\mathrm{Xx}$ \\
\cline { 2 - 5 } Pengeluaran: & & & & \\
Pembelian-pembelian tunai & $\mathrm{xx}$ & $\mathrm{xx}$ & $\mathrm{xx}$ & $\mathrm{xx}$ \\
Pembayaran upah & $\mathrm{xx}$ & $\mathrm{xx}$ & $\mathrm{xx}$ & $\mathrm{xx}$ \\
Pembayaran lain-lain & $\mathrm{xx}$ & $\mathrm{xx}$ & $\mathrm{xx}$ & $\mathrm{xx}$ \\
\hline
\end{tabular}




\begin{tabular}{|l|c|c|c|c|}
\hline Total pembayaran & $\mathrm{xx}$ & $\mathrm{xx}$ & $\mathrm{xx}$ & $\mathrm{Xx}$ \\
\cline { 2 - 4 } \\
Kelebihan-Kekurangan & $(\mathrm{xx})$ &
\end{tabular}

Sedangkan utang muräbahah nampaknya sulit menjadi pilihan dalam mengatasi kasus seperti ini. Walaupun utang muräbahab ini dilakukan sebatas menutupi masalah defisit saja, dan walaupun tanggung jawab pembayaran utang ini ada di tangan shabib al-mal, yang dalam hal ini dimanifestasikan dalam perusahaan yang dimilikinya, dan berimplikasi terhadap penanggungan semua beban yang berkaitan dengan utang murabahah, namun prinsip syariah tetap menolak modal mudhârabah diambil dari harta yang berstatus utang. Setidaknya inilah yang dikatakan oleh al-Syafici (767-820/150-204), Abu Hanifah (699767/80-150), dan para ahli fiqh lainnya.

Dalam kasus ini, perbedaan restrukturisasi pembiayaan mudarabah dengan pengambilan kredit utang berbunga terletak pada ada atau tidaknya nilai kewajiban yang dikenakan kepada perusahaan. Mekanisme bunga akan membebankan segala bentuk utang pinjaman menurut pokok pinjaman dan nilai waktu uang kepada perusahaan. Perusahaan tersebut dikatakan berutang kepada pihak pemberi pinjaman. Sedangkan mekanisme restrukturisasi pembiayaan mudharabah hanya menambah beban modal yang akan ditanggung oleh pihak shabib al-mal. Pihak mudharib, yang dalam hal ini mengoperasikan perusahaan, sama sekali tidak dibebankan terhadap nilai defisit tersebut. Ia hanya menghadapi tanggung jawab operasional yang lebih besar karena adanya penambahan modal tersebut.

Dilihat dari kemampuannya mengatasi masalah, sistem restrukturisasi pembiayaan mudharabah memiliki jangkauan kerja yang sama luasnya dengan pinjaman berbunga. Ia tidak hanya dapat mengatasi defisit yang terjadi pada pembelian barang, tetapi juga dapat mengatasi defisit yang terjadi pada upah tenaga kerja. Hal ini tidak dapat dilakukan oleh sistem murababah yang hanya berkonsentrasi pada objek yang berbentuk barang. Itulah sebabnya 


\section{Cash Budget dalam Sistem Bisnis Syariah}

maka cash budget perusahaan Islami yang mengalami defisit lebih tepat diatasi melalui sistem restrukturisasi pembiayaan mudharabah.

\section{Model Aplikasi Cash Budget Syariah}

Cash budget untuk sebuah perusahaan Islami yang dikondisikan menurut sistem restrukturisasi pembiayaan mudharabah dicontohkan sebagai berikut.

\section{Table 3.}

Cash Budget of International Al-Karimah Corporation

(2012, from January to April)

\begin{tabular}{|l|c|c|c|c|}
\hline \multicolumn{1}{|c|}{ Keterangan } & Jan & Feb & Mar & Apr \\
\hline Transaksi usaha: & & & & \\
Penerimaan & & & & \\
$\quad$ 1. Penjualan kredit & - & 100 & 200 & 320 \\
2. Penjualan tunai & 800 & 800 & 1.200 & 1.600 \\
\hline Jumlah diterima & 800 & 900 & 1.400 & 1.920 \\
\hline Pengeluaran: & 250 & 250 & 500 & 750 \\
1. Pembelian bahan & 250 & 750 & 500 & 750 \\
2. Pembayaran upah & 50 & 750 & 100 & - \\
3. Pembayaran lain & 550 & 1.750 & 1.100 & 1.500 \\
\hline Jumlah keluar & 250 & $(850)$ & 300 & 420 \\
\hline Kelebihan (kekurangan) & & & & \\
Saldo AB & 500 & $(350)$ & $(50)$ & 370 \\
Rp. 250 & & & & \\
& & & & \\
Transaksi Finansial: & 250 & 500 & 50 & 350 \\
Saldo PB & - & 400 & - & - \\
Terima tambahan modal mudhârabah & 250 & 900 & 50 & 350 \\
\hline Jumlah & 250 & $(850)$ & 300 & 420 \\
Kelebihan (kekurangan) & 500 & 50 & 350 & 770 \\
\hline Saldo AB & & & & \\
\hline
\end{tabular}

Dalam kasus ini disebutkan bahwa di bulan Januari 2012, PT. AlKarimah Internasional mendapatkan penerimaan sebesar Rp. 800.000.000. Sumber penerimaan ini berasal dari penjualan tunai. Sementara penerimaan dari penjualan kredit pada bulan ini tidak ada. Adapun jumlah pengeluaran pada bulan ini sebesar Rp. 550.000.000. Jumlah ini terdiri dari pembelian bahan sebesar Rp. 250.000.000, pembayaran upah sebesar Rp. 250.000.000, 
dan pembayaran lain-lain sebesar Rp. 50.000.000. Selisih jumlah penerimaan dengan jumlah pengeluaran di bulan ini cukup baik, karena perusahaan mendapatkan kelebihan dari hasil pengurangan biaya sebesar Rp. 250.000.000. Nilai kelebihan ini ditambahkan dengan saldo bulan yang lalu sebesar Rp. 250.000.000, sehingga saldo di bulan ini menjadi Rp. 500.000.000.

Permasalahan kemudian timbul di bulan Februari. Pada bulan ini, perusahaan mengalami defisit sebesar Rp. 850.000.000. Defisit ini terjadi karena jumlah penerimaan sebesar Rp. 900.000.000 tidak dapat menutupi jumlah pengeluaran sebesar Rp. 1.750.000.000. Nilai saldo yang hanya sebesar Rp. 500.000.000 tidak dapat menutupi defisit ini. Alasannya, walaupun perusahaan tersebut telah menutupi defisit dengan semua nilai saldonya, perusahaan tersebut tetap mengalami defisit sebesar Rp. 350.000.000.

Pada titik inilah perusahaan tersebut perlu mendapatkan jalan keluar. Berdasarkan pada prinsip keuangan syariah, perusahaan yang terdiri dari shabib al-mal dan mudharib ini dapat melakukan restrukturisasi nilai pembiayaan yang defisit tersebut. Restrukturisasi ini dapat diajukan oleh mudharib kepada shahib al-mal. Hal yang perlu dilakukan dalam restrukturisasi ini ialah memperhitungkan tambahan nilai pembiayaan secara proporsional dengan cara menjumlahkan nilai saldo minimal yang wajar dengan nilai defisit. Rumusan ini disebutkan sebagai berikut.

\section{Saldo Minimal yang wajar + Defisit = Besarnya Tambahan Pembiayaan}

Saldo minimal yang wajar dimasukkan dalam rumusan ini untuk memberikan keamanan bagi perusahaan. Sedangkan defisit merupakan nilai yang harus ditutupi dalam kasus ini. Jika saldo minimal yang wajar bagi perusahaan adalah Rp. 50.000.000, maka tambahan nilai pembiayaan dalam restrukturisasi ini adalah Rp. 400.000.000. Nilai ini terdiri dari saldo minimal yang wajar Rp. 50.000.000 dan defisit Rp. 350.000.000. Dengan adanya jalan keluar ini, maka perusahaan dapat melanjutkan aktifitas usaha dengan baik di bulan berikutnya.

Pada dua bulan berikutnya, perusahaan meningkatkan produktifitasnya sehingga menghasilkan kelebihan-kelebahan yang sangat berarti. Pada bulan Maret, kelebihan yang diraih oleh perusahaan sebesar Rp. 


\section{Cash Budget dalam Sistem Bisnis Syariah}

300.000.000. Hal ini menambah saldo perusahaan dari Rp. 50.000.000, yang merupakan nilai saldo minimal yang wajar, menjadi Rp. 350.000.000. Sedangkan pada bulan April, kelebihan yang diraih perusahaan adalah Rp. 420.000.000. Angka ini dapat memperbesar saldo sebelumnya sehingga menjadi Rp. 770.000.000. Terlihat setelah mengalami restrukturisasi, perusahaan mengalami peningkatan usaha yang luar biasa. Jika restrukturisasi ini tidak dilakukan, maka perusahaan akan terperangkap oleh beban utang yang sangat menyulitkan. Beban yang tidak terselesaikan ini akan mempengaruhi kinerja usaha di bulan berikutnya.

Agar kita mendapatkan gambaran mengenai kemampuan perusahaan keluar dari masalah, mari kita lihat alur cash budget pada bagian finansial, mulai dari bulan Februari. Di bulan ini, setelah saldo bulan lalu ditambah nilai restrukturisasi, jumlah finansial yang dimiliki perusahaan adalah Rp. 900.000.000. Jumlah ini digunakan untuk menutupi defisit kas sebesar Rp. 850.000.000. Pengurangan ini menyisakan nilai saldo minimal yang wajar sebesar Rp. 50.000.000. Pada bulan berikutnya perusahaan tidak mengalami defisit. Hal ini menjadikan nilai finansial perusahaan selalu positif. Setiap kelebihan yang masuk ke dalam kas perusahaan akan selalu ditambahkan dengan saldo bulan yang lalu. Di bulan April, saldo akhir bulan yang dimiliki perusahaan adalah Rp. 770.000.000. Nilai ini berasal dari hasil penambahan, yakni kelebihan nilai penjualan sebesar Rp. 420.000.000 ditambah dengan nilai saldo bulan sebelumnya sebesar Rp. 770.000.000. Jika penjualan tidak mengalami defisit kembali, maka di bulan-bulan berikutnya nilai saldo perusahaan akan terus bertambah. Penambahan-penambahan ini akan memperbesar nominal bagi hasil bagi pihak shahib al-mal dan mudharib.

\section{Kesimpulan}

Dengan tidak menghadirkan bunga, cash budget sebuah perusahaan Islami dapat dijalankan melalui sistem mudharabah. Sistem pembiayaan ini dibangun atas prinsip kerjasama di mana urusan finansial sepenuhnya berada di bawah tanggungjawab shabib al-mal dan urusan operasional di bawah tanggungjawab mudharib. Permasalahan defisit diatasi melalui restrukturisasi modal mudharabah di mana pihak shabib al-mal menambahkan nilai defisit yang 
harus segera diatasi. Nilai restrukturisasi tersebut dikeluarkan melalui penambahan variabel saldo yang wajar dengan defisit riil. Melalui pola kerjasama ini terlihat bahwa sistem cash budget membangun sebuah bisnis yang sinergis di mana risiko tidak hanya dibebankan kepada pengusaha mudharib (eksekutif perusahaan) namun juga menjadi tanggungjawab shabib al-mal. Mereka menjalankan prinsip ta'awun yang tidak hanya menyamakan posisi dan kedudukan tetapi juga saling berkontribusi dalam peran dan tanggungjawab. 
Cash Budget dalam Sistem Bisnis Syari'ah

\section{DAFTAR PUSTAKA}

Abdullah, Daud Vicary and Keon Chee. 2010. Islamic Finance Why It Makes Sense. Singapore: Marshall Cavendish.

Choudhury, Masudul Alam. 1986. Contributions to Islamic Economic Theory A Study in Social Economics. New York: St. Martin's Press.

El Tiby, Amr Mohamed. 2011. Islamic Banking How to Manage Risk and Improve Profitability. New Jersey: John Wiley \& Sons, Inc.

Khan, M. Fahim. 1995. Essays in Islamic Economics. Leicester: The Islamic Foundation.

Kharota, Ala Eddin. 1997. Transactions in Islamic Law. Kuala Lumpur: A.S. Noordeen.

Rusyd, Ibn. 2008. Bidayat al-Mujtabid wa Nihayat al-Muqtashid. Beirut: Dar alFikr.

Zuhaili, Wahbah. 2007. Fiqh al-Mu'alamah al-Mu'ashirah. Beirut: Dar al-Fikr. 